\title{
Strategies for large bone defect reconstruction after trauma, infections or tumour excision: a comprehensive review of the literature
}

\author{
Filippo Migliorini ${ }^{1 *}\left(\mathbb{C}\right.$, Gerardo La Padula ${ }^{2}$, Ernesto Torsiello², Filippo Spiezia ${ }^{3}$, Francesco Oliva ${ }^{2}$ and \\ Nicola Maffulli ${ }^{2,4,5}$
}

\begin{abstract}
Large bone defects resulting from musculoskeletal tumours, infections, or trauma are often unable to heal spontaneously. The challenge for surgeons is to avoid amputation, and provide the best functional outcomes. Allograft, vascularized fibular or iliac graft, hybrid graft, extracorporeal devitalized autograft, distraction osteogenesis, inducedmembrane technique, and segmental prostheses are the most common surgical strategies to manage large bone defects. Given its optimal osteogenesis, osteoinduction, osteoconduction, and histocompatibility properties, along with the lower the risk of immunological rejection, autologous graft represents the most common used strategy for reconstruction of bone defects. However, the choice of the best surgical technique is still debated, and no consensus has been reached. The present study investigated the current reconstructive strategies for large bone defect after trauma, infections, or tumour excision, discussed advantages and disadvantages of each technique, debated available techniques and materials, and evaluated complications and new perspectives.
\end{abstract}

Keywords: Bone defect, Biological, Autologous, Graft

\section{Introduction}

Large bone defects resulting from musculoskeletal tumours, infections or trauma represent a tissue deficit unable to heal spontaneously even with adequate care and surgical stabilization $[1,2]$. Surgical management aims to reconstruct the defect, avoiding amputation and providing acceptable functional outcomes [3]. Reconstruction can involve massive intercalary replacement when the whole diaphysis is replaced [4], or joint components, in association, if necessary, with prosthetic elements $[5,6]$. Intercalary reconstructions showed better

${ }^{*}$ Correspondence: migliorini.md@gmail.com

${ }^{1}$ Department of Orthopaedic, Trauma, and Reconstructive Surgery, RWTH University Hospital, Pauwelsstraße 30, 52074 Aachen, Germany

Full list of author information is available at the end of the article functional outcomes compared to other limb salvage procedures from lower morbidity of the adjacent joints [7]. Reconstructive management for large bone defects can involve autograft, allograft and non-biological materials [8]. Autografts such as vascularized fibular graft [9] or vascularized iliac bone graft $[10,11]$ are considered the gold standard for reconstruction of post-traumatic bone defects with non-union or malunion, given their properties of osteogenesis, osteoinduction, osteoconduction, and histocompatibility, leading to a low risk of immunological rejection [12-14]. Disadvantages are the limited amount of bone graft available, infection, prolonged wound drainage, and reoperation of the donor site [15, 16]. Another type of autograft, after bone tumour resection, consists in the re-use of the excised bone segment. For this technique, the bone segment should be processed original author(s) and the source, provide a link to the Creative Commons licence, and indicate if changes were made. The images or other third party material in this article are included in the article's Creative Commons licence, unless indicated otherwise in a credit line to the material. If material is not included in the article's Creative Commons licence and your intended use is not permitted by statutory regulation or exceeds the permitted use, you will need to obtain permission directly from the copyright holder. To view a copy of this licence, visit http://creativecommons.org/licenses/by/4.0/. The Creative Commons Public Domain Dedication waiver (http://creativeco mmons.org/publicdomain/zero/1.0/) applies to the data made available in this article, unless otherwise stated in a credit line to the data. 
by pasteurization, autoclaving, gamma irradiation or cryotherapy, resulting in reduction of graft osteogenicity and osteoinductivity [17-19]. Allografts represent a valid alternative to autografts, and are commonly used after bone tumour resection [20]. The main advantages of these grafts are their relative abundance, which allows reconstruction even after massive bone defect, and the absence of morbidity of the donor site [21]. The disadvantages, on the other hand, are immunological rejection and the risk of transmissive diseases, such as HIV and Hepatitis C [22-24]. However, these latter are reduced by modern screening methods $[21,23]$. Bone cement spacers and induced-membrane technique is another alternative available for the reconstruction of bone defects [25, 26]. This technique is used to manage infected or uninfected bone defects $[27,28]$. However, these techniques exhibit poor bone integration and slow remodelling, which make them more suitable for the reconstruction of upper limb defects, as mechanical failure is a frequent complication in the lower limb [4]. The main non-biological materials are segmental endoprosthesis [4, 21]. Segmental prostheses have several advantages, such as immediate stability, rapid rehabilitation, and early weight bearing [24]. The disadvantages, on the other hand, are infections, mechanical loosening, mechanical wear, and prosthetic and periprosthetic fracture [21, 29]. The choice of the best surgical technique is still debated, and no consensus has been reached. The present study investigated current reconstructive strategies for large bone defect after trauma, infections, or tumour excision, discussed advantages and disadvantages of each technique, debated available techniques and materials, and evaluated complications and new perspectives.

\section{Reconstruction using biological materials}

Biological reconstructions can be managed through viable or non-viable bone material [4]. Viable bone material was considered the gold standard for reconstruction of post-traumatic bone defects from non-union or malunion, given its properties of osteogenesis, osteoinduction, osteoconduction, and histocompatibility, given its low risk of immunological rejection and a high rate of neoformation of bone [12, 13, 30]. Vascularized fibular graft, vascularized iliac bone graft, bone lengthening utilizing external fixation, and the induced-membrane technique are all examples of reconstruction techniques using viable bone [9-11]. Allograft, a biological reconstruction technique through non-viable bone, is used in reconstruction after resection of a bone tumour $[6,20$, 21]. The combined reconstruction with a vascularized fibula and an allograft has the advantages of both previously described techniques [31]. Furthermore, among the reconstruction techniques which use non-viable bone material, the re-use of resected tumour bone can also be included [32]. For this purpose, the bone segment must be processed by pasteurization, gamma irradiation, or cryotherapy [17-19].

\section{Vascularized fibular graft}

Vascularized fibular grafts are commonly used to reconstruct bone defects larger than $6 \mathrm{~cm}$, after infection, tumour excision, and trauma [33], often in combination with soft tissue defects [34]. Three different options of vascularized fibular graft have been developed: single vascularized fibular graft, double-barrel technique, and combined vascularized fibula and allograft reconstruction $[4,35,36]$. In adult patients, a fibular graft up to $25-26 \mathrm{~cm}$ can be harvested [21,37]. The proximal fibula and the lateral malleolus should be spared to maintain knee and ankle joint stability, protect the common peroneal nerve, and preserve weight-bearing capacity $[9,21$, $33,35,37]$. A classical single vascularized fibular graft (Fig. 1), having a reduced cross section, could be at risk of stress fractures if used in the lower limbs [34, 38, 39]. To prevent them, techniques such as the double-barrel technique and the combined vascularized fibula and allograft reconstruction have been developed [38]. Indications for single vascularized fibular graft are upper extremity

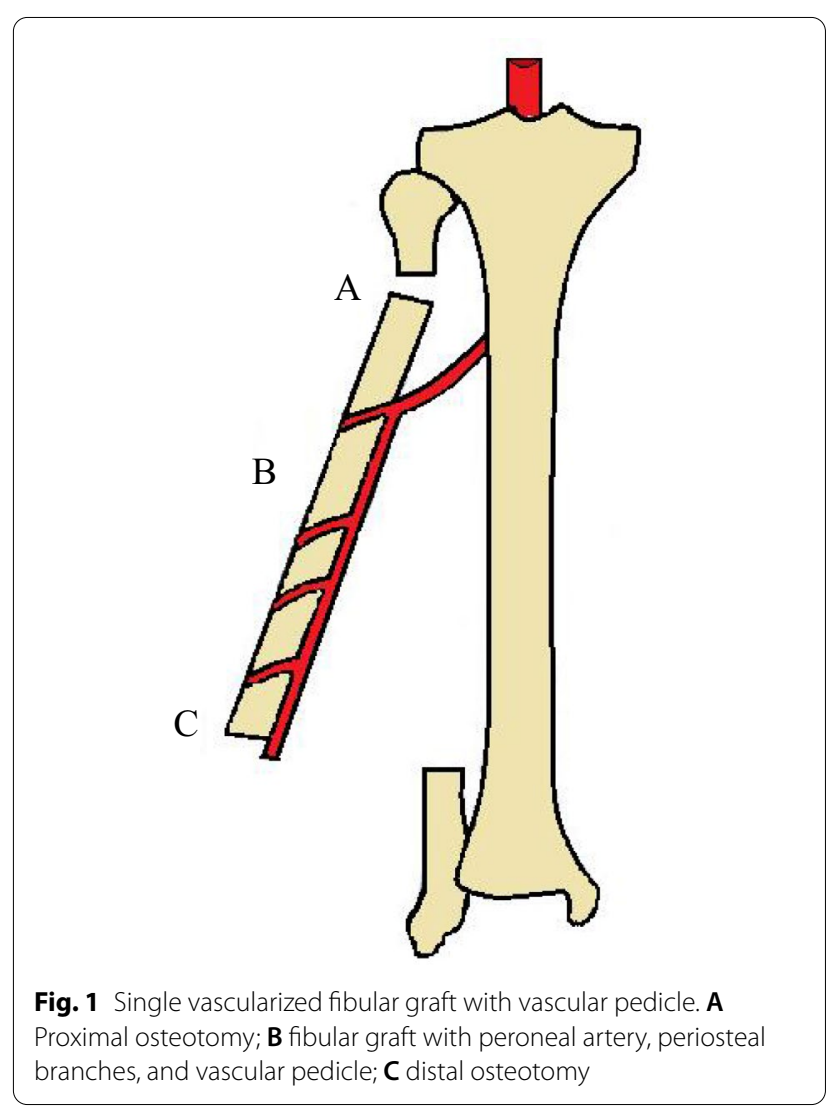


reconstruction, tibial defect, bone defect in paediatric patients and in general all areas under lighter stress load $[4,40]$. In the double-barrel technique, the fibular graft, thanks to its dual vascularization and adequate blood supply, can be transversely osteotomized to produce two pieces $[38,41]$. This procedure, which allows the graft to double its cross section and increase its weight-bearing capacity [38, 41, 42], is particularly suitable for reconstruction of the femur and pelvis [38, 42]. However, the bone defect for which this technique can be used must not exceed $13 \mathrm{~cm}$ in length [41]. Complications such as infections, fixation failure and graft fracture have been reported [40, 43-45], but the rate of union was $82 \%$ at 2 years and $97 \%$ at 5 years. Union was achieved without further surgery in $70 \%$ of patients at a mean of 10 months post-operatively. Major complications such as deep softtissue infection, thrombosis of the pedicle, stress fracture not associated with fixation failure, compartment syndrome, and vascular injury have been reported. Liu et al. [46], in a long-term follow-up of fibular graft, reported union rates of $100 \%$ and mean union time of 21.3 weeks.

\section{Combined vascularized fibula and allograft reconstruction or hybrid graft}

First described by Capanna et al. in the early 1990s [47], this technique consists of combining the advantages provided by the mechanical strength of allografts and the advantages of the biological properties of the autograft $[31,48]$. The allograft mainly provides bone support and early stability, while the vascularized fibula facilitates the integration between host and allograft, and has the ability to rapidly consolidate $[31,49,50]$. This hybrid graft can be assembled by the intramedullary or the onlay technique $[50,51]$. The intramedullary technique consists of inserting the vascularized fibula inside the allograft (Fig. 2). For this purpose, the anterolateral cortex of the allograft is opened and the medullary canal reamed for a length suitable to accommodate the fibula [50-52]. When the fibula is inserted into the autograft, particular attention should be paid not to damage the vascular pedicle [52]. This technique is indicated in massive intercalary reconstruction of femur and tibia, especially in patients with long life expectancy and high physical demands $[33,50,52]$. A common complication associated with this technique is thrombosis of the anastomosed vessels, which can lead to failure of the graft [48]. Uncontrolled bleeding, stress fractures, delayed or failed bone consolidation, delayed bone growth, persistence of deformity, infections, and compartment syndrome are complications associated with the technique $[9,33,50,53,54]$. The overall limb salvage rate was $94 \%$, hybrid graft fractures occurred in $23 \%$, and infection in $6 \%$ [54]. The median time to full weight-bearing with a removable orthosis

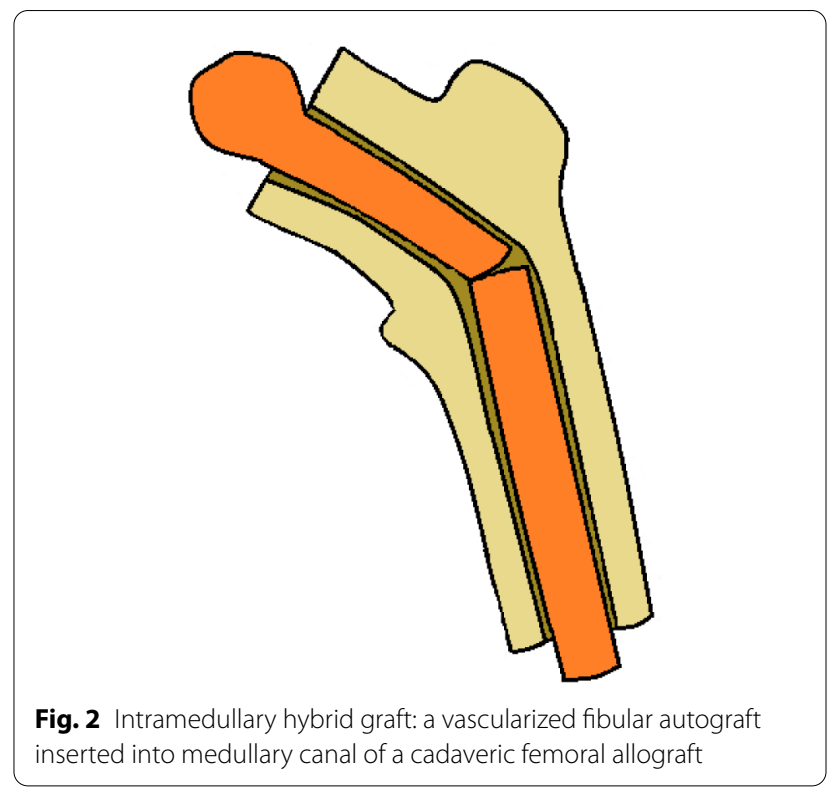

was 3.5 months, consolidation of the proximal anastomosis was achieved over a median of 6 months, four of the seven grafts fractured in the distal anastomosis between 6 and 14 months after surgery. After reoperation, consolidation of the distal anastomosis was observed after 2.8 months [50].

\section{lliac crest bone graft}

Iliac crest bone grafting is another commonly used strategy to reconstruct bone defects secondary to infection, tumour excision and fractures $[55,56]$. Iliac crest bone graft presents all the advantages of autografts: osteogenesis, osteoinduction, osteoconduction, and histocompatibility [57-60]. The bone graft can be harvested from the anterior or the posterior iliac crest [61]. The anterior iliac crest is harvested about $4-5 \mathrm{~cm}$ posterior to the anterior superior iliac spine [62,63], with a length that does not exceed $30 \mathrm{~mm}$ to prevent iliac crest stress fracture [64, 65]. Many techniques to harvest the anterior iliac crest have been developed, such as trapdoor technique, tricortical technique [62, 63], segmental bicortical technique, iliac crest-splitting technique, trephine technique, and acetabular reamer technique [63]. These procedures all access the inner or outer table of the ileum to harvest the cortico-cancellous graft or pure cancellous graft [63]. Accessing the posterior iliac crest allows to harvest a segment up to $30 \mathrm{~cm}$ long, and it is therefore indicated when a large graft volume is required. The trapdoor technique is particularly effective to obtain a cancellous graft from the posterior ileum [63]. The traditional harvesting technique to obtain an iliac graft may be associated with several complications. The complications that occur after 
the harvest of the autogenous iliac crest can be divided into major and minor, which occur, respectively, in $10 \%$ and $5.8 \%$ of patients [10]. Major complications are vascular injury, nerve injury, donor defect hernias, deep infection, deep hematomas, and iliac wing fractures. Minor complications are superficial infection, minor hematomas, and superficial seromas. Calori et al. [66] compared complications related to the donor site using traditional iliac crest bone graft harvest and the reamer irrigator aspirator (RIA) [60, 67, 68] technique. They noted that $14.28 \%$ of patients with iliac harvesting reported pain at the donor site, while no pain was reported by patients who underwent RIA. Infection at the donor site did not occur in any patient undergoing RIA, while $14.28 \%$ of patients undergoing iliac harvesting presented an infection. Finally, no patient operated with RIA presented a fracture at the donor site, while $2.8 \%$ of the patients who underwent iliac harvesting presented an anterior superior iliac spine fracture.

\section{Reconstruction by distraction osteogenesis}

Described by Ilizarov in the 1950s [69], distraction osteogenesis has been applied to correct bone deformities, congenital musculoskeletal pathologies, manage bone defects following trauma, infections, and in cancer surgery [70-72]. In the past decades, distraction osteogenesis was seldom performed, as it was believed to cause tumour recurrence [21, 70]. Indeed, distraction osteogenesis can only be performed when full tumour resection is achieved $[21,70,73]$. Three different procedures for bone reconstruction after tumour resection have been described: segmental transport, shortening-distraction with an external fixation (Fig. 3), and shortening-distraction with an intramedullary nail to shorten the time of use of external fixation. Given the long time required for external fixation, this technique is only useful if the defect is between 4 and $6 \mathrm{~cm}$ [70]. Distraction begins gradually 7-14 days after surgery, with a maximum amount of $1 \mathrm{~mm}$ of bone distraction per day. Each millimetre of bone distraction requires approximately 2 days to consolidate $[4,21,70]$. Long-term external fixation, in addition to being uncomfortable for the patient, increases the risk of superficial and deep infections, loosening of the pins, and rotational and axial deviation [21, 70, 72, 74]. This technique regenerates living viable bone tissue to repair the bone defect $[21,75]$. Schep et al. [76] reported a mean of 1.5-month distraction osteogenesis to achieve a growth of $1 \mathrm{~cm}$ for post-traumatic lower limb defects, and a rate of pin tract infections of 53\%. Demiralp et al. [75] reported a mean time of 28 days per $\mathrm{cm}$ for intercalary bone defect reconstruction following bone tumour resection, and a rate of $61.5 \%$ of pin tract infections.

\section{Bone cement spacer and induced-membrane technique}

The induced-membrane technique or Masquelet technique is used for bone defect reconstruction after infection, tumour excision and fractures [4, 25, 77]. This technique is performed in two steps (Fig. 4). The first phase consists of debridement, followed by the insertion of a polymethylmethacrylate spacer into the bone defect [78-80]. Polymethylmethacrylate causes a mild foreignbody inflammatory response which induces the development of a thick pseudo-synovial membrane which acts as a newly performed periosteum [78, 79, 81, 82]. This pseudomembrane is highly vascularized and rich in growth factors $[78,79]$. The second phase, which begins after 6-8 weeks, involves opening the membrane and removing the spacer, replacing it with a bone graft $[4,25$, $79,83]$. The spacer is a local antibiotic carrier, it reduces dead space, and, for this reason, it is especially indicated

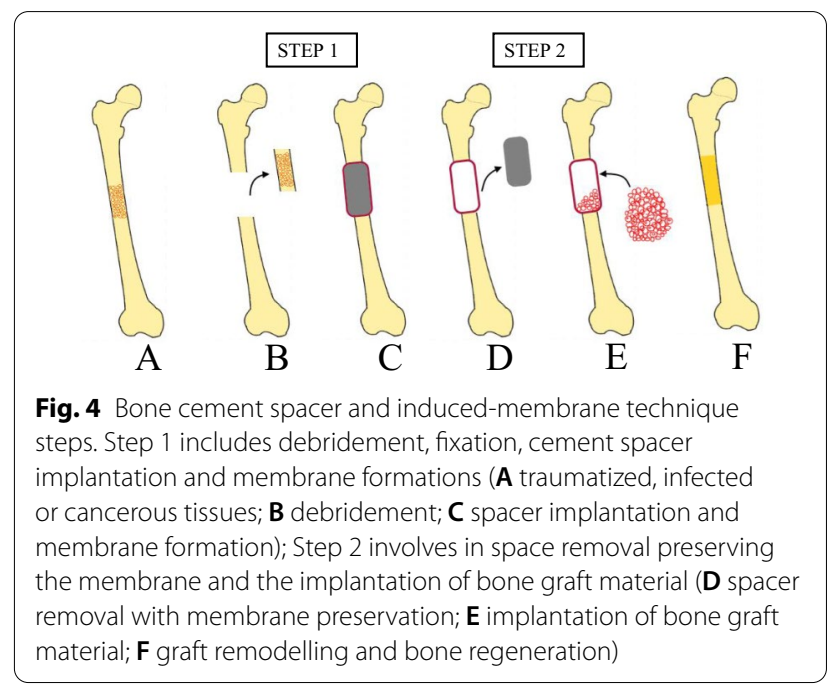


in the management of infected bone defects [25, 83]. However, this technique showed slow bone integration and a fair amount of graft remodelling [4, 84]. It is commonly preferred for upper limb defect reconstruction, given its high failure rate in lower limb reconstruction from mechanical failure [4]. Lemos Azi et al. [25] conducted a study on the induced-membrane technique and demonstrated that infection occurred in $68 \%$ of patients, and soft tissue reconstruction was required in $32 \%$ of patients. Bone union was achieved in $91 \%$ of patients within a mean time of 8.5 months.

\section{Extracorporeal devitalized autograft reconstructions}

Recycling of the tumour-bearing bone segment is an alternative to allograft to repair bone defects following cancer surgery [85]. Several techniques have been developed to remove tumour cells from the resected bone fragment and make it reimplantable, including irradiation, pasteurization, and cryotherapy [18]. A most important advantage is that the processed autograft has the exact shape of the bone defect. This is particularly suitable for reconstructions in anatomically difficult tumour sites [86]. Other advantages are a low immunogenic response, absence of disease transmission, anallergicity, the no need for a bone bank, and the possibility of overcoming cultural objections to allograft found in some countries and cultures. Disadvantages include the risk of infection, fracture, bone resorption, graft necrosis, and delayed union or non-union $[4,21,86]$.

\section{Extracorporeal irradiated autograft}

Described by Spira and Lubin in 1968 [87], this technique consists of extracorporeal irradiation with reimplantation of a tumour-bearing bone $[88,89]$. The first step is to remove the tumour mass with an appropriate margin, along with its surrounding soft tissues $[4,90]$. Tendons and ligaments are preserved to be reused after irradiation $[8,89]$. Irradiation consists of $60-70$ Gy in a single dose $[88,90]$. A limitation of this procedure is that the irradiated bone fragments have no blood supply and this can lead to infections, fractures, non-union, and bone re-absorption [90, 91]. To avoid this problem, a vascularized bone graft can be associated with the irradiated bone fragment, improving reconstruction and increasing vascularization $[4,89,90]$. Oike et al. [89] reported that there were no recurrences in the irradiated autograft, and $88.9 \%$ survived. Non-union occurred in $33.3 \%$, deep infections in $14.8 \%$, and subchondral bone collapse was observed in $14.8 \%$. Mihara et al. [90] reported that vascularized bone grafting was successful and survived in $93.3 \%$ of patients, with $85.7 \%$ of these patients achieving complete bone union at an average of 10.8 months (range 5-24 months).

\section{Extracorporeal pasteurized autograft}

Pasteurization consists in subjecting the tumour-bearing bone to a temperature of about $65^{\circ} \mathrm{C}$ for $30-60 \mathrm{~min}$, thus killing the tumour cells, without altering the osteoinductivity and mechanical resistance of the graft [92-94]. After extracorporeal pasteurization, the treated bone is relocated to its native site and fixed with plates and screws [95]. In a comparative study, among the different methods of extracorporeal devitalization of the autograft, pasteurization produced better formation of callus and better preservation of osteocytes and bone marrow cellularity [17]. The 5,10 , and 20 -year survival rates of pasteurized bones, calculated using the KaplanMeier method, were $73 \%, 59 \%$, and $40 \%$, respectively [93]. Unfortunately, $38 \%$ of the extracorporeal pasteurized autografts were removed because of serious complications. The major complications are infection in 13\% of patients, non-union in $7 \%$, fracture of the graft in $6 \%$, failure of fixation in 5\%, resorption of the graft in 5\%, and local recurrence in $4 \%$ [93].

\section{Extracorporeal frozen autograft}

The freezing technique uses liquid nitrogen with temperatures to $-166{ }^{\circ} \mathrm{C}$ to destroy cancer cells [96]. The freezing technique induces ice crystal formation and cell dehydration [97]. Furthermore, freezing can also cause thrombosis of the microcirculation, inducing ischaemic necrosis of the tumour $[4,96,98]$. The technique involves three steps: the bone fragment is immersed for $20 \mathrm{~min}$, thawed for $15 \mathrm{~min}$ at room temperature, and rinsed with distilled water for $10-15 \min [4,9,99,100]$. There are two different procedures to manage the affected bone segment: free freezing and pedicle freezing technique [99] (Fig. 5). The free freezing technique involves two osteotomies [101] and soft tissue removal by immersion of neoplastic bone in liquid nitrogen $[99,100]$. The pedicle freezing technique requires a single osteotomy

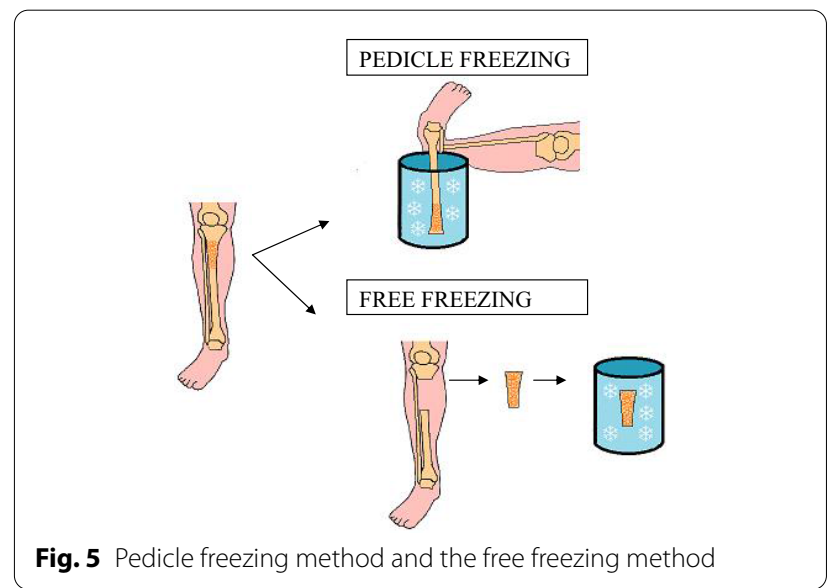


or joint dislocation on the proximal side of the tumourbearing bone [102]. After the osteotomy or joint dislocation, the bone is rotated and placed in a container filled with liquid nitrogen [99, 102]. Cryotherapy procedures have a number of advantages for the bone, as it retains good osteoinduction and osteoconduction properties, biomechanical strength, with no risk of disease transmission and less immunological reaction. Moreover, freezing requires less equipment than other recycling techniques $[4,96,100]$. Zekry et al. [99] reported that 5 - and 10-year survival rates of frozen autografts were $91.2 \%$, and bone union rate was $97 \%$, but fractures occurred in $17.6 \%$ of patients, with local recurrence of disease from surrounding soft tissue in $11.8 \%$ of patients. Lu et al. [103] compared the frozen autograft with the Capanna's technique, with no differences in the two operative procedures in terms of resection length, surgery duration, and blood loss. The mean union time for the frozen autograft was 8.4 months, significantly shorter than the Capanna's method, which had a mean union time of 14.1 months. There are also differences between the two groups in terms of complications: infection and delayed union were observed in $6.7 \%$ and $13.3 \%$, respectively, in the Capanna's group, while no such complications were observed in the patients treated with frozen autograft.

\section{Reconstruction using non-biological materials Segmental prosthesis}

Segmental prostheses (Fig. 6) are an alternative for intercalary reconstructions [4]. They allow immediate stability, rapid rehabilitation, and early weight bearing [24, 104]. Common complications are infections, mechanical loosening, and mechanical wear [24].

The high risk of prosthetic and periprosthetic fracture has made this technique preferred in patients with limited life expectancy from myeloma, lymphoma, or metastatic bone cancer [21, 24, 104]. Therefore, elderly patients or patients with a limited life expectancy, in
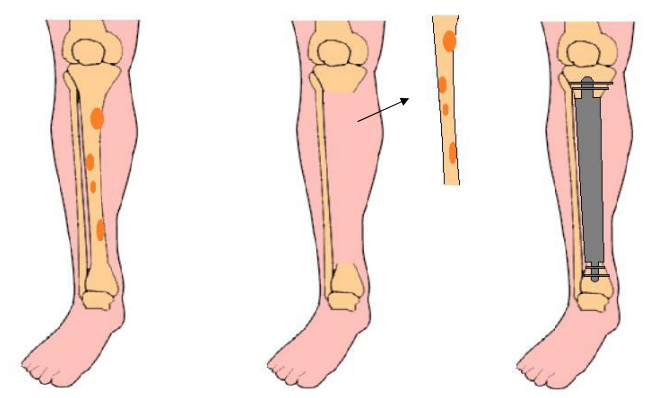

Fig. 6 Illustration showing a large bone defect after bone tumour resection and reconstruction with a segmental prosthesis whom immediate restoration of function and stability is more important than durability, are the best candidates for this technique [4, 24]. Henderson et al. [105] reported a segmental prosthesis failure rate of $24.5 \%$, of which $49 \%$ were mechanical and 51\% non-mechanical. Five failure modes were identified: the most common was infection, which occurred in $34 \%$ of patients, then failures from soft tissue problems around the implant, which were observed in $12 \%$ of patients, aseptic loosening in $19 \%$, structural failures in $17 \%$, and failure from tumour progression in $17 \%$.

\section{Conclusions}

The management of large bone defects remains a challenge. The choice of technique is still debated, and consensus is lacking. Several techniques are available to manage bone defects; however, the lack of quantitative data, along with the limited quality evidence, does not allow to infer solid conclusions. Further investigations are necessary to provide quantitative data on the rates of complication and reoperation.

\section{Abbreviation}

RIA: Reamer irrigator aspirator.

\section{Acknowledgements \\ None.}

\section{Authors' contributions}

FM: conceptualization, writing, revision, and final approval; GLP: writing, revision, and final approval; ET: revision and final approval; FS: revision and final approval; FO: supervision and final approval; NM: supervision, revision, and final approval. All authors read and approved the final manuscript.

Funding

Open Access funding enabled and organized by Projekt DEAL.

Availability of data and materials

Not applicable.

\section{Declarations}

Ethics approval and consent to participate Not applicable.

\section{Consent for publication \\ Not applicable.}

\section{Competing interests}

The authors declare that they have no competing interests.

\section{Author details}

'Department of Orthopaedic, Trauma, and Reconstructive Surgery, RWTH University Hospital, Pauwelsstraße 30, 52074 Aachen, Germany. ${ }^{2}$ Department of Medicine, Surgery and Dentistry, University of Salerno, Via S. Allende, 84081 Baronissi, SA, Italy. ${ }^{3}$ Ospedale San Carlo Potenza, Via Potito Petrone, 85100 Potenza, Italy. ${ }^{4}$ School of Pharmacy and Bioengineering, Keele University Faculty of Medicine, Thornburrow Drive, Stoke on Trent, England. ${ }^{5}$ Barts and the London School of Medicine and Dentistry, Centre for Sports and Exercise Medicine, Mile End Hospital, Queen Mary University of London, 275 Bancroft Road, London E1 4DG, England. 
Received: 28 May 2021 Accepted: 20 September 2021

Published online: 02 October 2021

\section{References}

1. El-Rashidy AA, Roether JA, Harhaus L, Kneser U, Boccaccini AR. Regenerating bone with bioactive glass scaffolds: a review of in vivo studies in bone defect models. Acta Biomater. 2017;62:1-28. https://doi.org/10. 1016/j.actbio.2017.08.030.

2. Nauth A, Schemitsch E, Norris B, Nollin Z, Watson JT. Critical-size bone defects: is there a consensus for diagnosis and treatment? J Orthop Trauma. 2018;32(Suppl 1):S7-11. https://doi.org/10.1097/BOT.00000 00000001115

3. Renard AJ, Veth RP, Schreuder HW, van Loon CJ, Koops HS, van Horn JR. Function and complications after ablative and limb-salvage therapy in lower extremity sarcoma of bone. J Surg Oncol. 2000;73(4):198-205. https://doi.org/10.1002/(sici)1096-9098(200004)73:4\%3c198::aid-jso3\% 3e3.0.co;2-x.

4. Zekry KM, Yamamoto N, Hayashi K, Takeuchi A, Alkhooly AZA, Abd-Elfattah AS, Elsaid ANS, Ahmed AR, Tsuchiya H. Reconstruction of intercalary bone defect after resection of malignant bone tumor. J Orthop Surg. 2019;27(1):2309499019832970. https://doi.org/10.1177/2309499019 832970.

5. Bai XS, Thomas JM, Ha AS. Surgical correction of articular damage in the knee: osteoarticular transplantation to joint reconstruction. Semin Musculoskelet Radiol. 2017;21(2):147-64. https://doi.org/10.1055/s0037-1599211.

6. Raskin KA, Hornicek F. Allograft reconstruction in malignant bone tumors: indications and limits. Recent Results Cancer Res. 2009;179:518. https://doi.org/10.1007/978-3-540-77960-5 5.

7. Bus MP, van de Sande MA, Taminiau AH, Dijkstra PD. Is there still a role for osteoarticular allograft reconstruction in musculoskeletal tumour surgery? A long-term follow-up study of 38 patients and systematic review of the literature. Bone Joint J. 2017;99-B(4):522-30. https://doi. org/10.1302/0301-620X.99B4.BJJ-2016-0443.R2.

8. Nishida J, Shimamura T. Methods of reconstruction for bone defect after tumor excision: a review of alternatives. Med Sci Monit. 2008;14(8):RA107-113.

9. Ou Q, Wu P, Zhou Z, Pan D, Tang JY. Complication of osteo reconstruction by utilizing free vascularized fibular bone graft. BMC Surg. 2020:20(1):216. https://doi.org/10.1186/s12893-020-00875-9.

10. Arrington ED, Smith WJ, Chambers HG, Bucknell AL, Davino NA. Complications of iliac crest bone graft harvesting. Clin Orthop Relat Res. 1996;329:300-9. https://doi.org/10.1097/00003086-199608000-00037.

11. Zhao Z, Yan T, Guo W, Yang R, Tang X, Wang W. Surgical options and reconstruction strategies for primary bone tumors of distal tibia: a systematic review of complications and functional outcome. J Bone Oncol. 2019;14: 100209. https://doi.org/10.1016/j.jbo.2018.100209.

12. Baldwin P, Li DJ, Auston DA, Mir HS, Yoon RS, Koval KJ. Autograft, allograft, and bone graft substitutes: clinical evidence and indications for use in the setting of orthopaedic trauma surgery. J Orthop Trauma. 2019;33(4):203-13. https://doi.org/10.1097/BOT.0000000000001420.

13. Beaman FD, Bancroft LW, Peterson JJ, Kransdorf MJ. Bone graft materials and synthetic substitutes. Radiol Clin North Am. 2006;44(3):451-61. https://doi.org/10.1016/j.rcl.2006.01.001.

14. Yamamoto N, Hayashi K, Tsuchiya H. Progress in biological reconstruction and enhanced bone revitalization for bone defects. J Orthop Sci. 2019;24(3):387-92. https://doi.org/10.1016/j.jos.2019.01.015.

15. Ghoneimy AME, Sherbiny ME, Kamal N. Use of vascularized fibular free flap in the reconstruction of the femur in pediatric and adolescent bone sarcomas: complications and functional outcome. J Reconstr Microsurg. 2019;35(2):156-62. https://doi.org/10.1055/s-0038-1668142.

16. Emori M, Kaya M, Irifune H, Takahashi N, Shimizu J, Mizushima E, Murahashi Y, Yamashita T. Vascularised fibular grafts for reconstruction of extremity bone defects after resection of bone and soft-tissue tumours: a single institutional study of 49 patients. Bone Joint J. 2017;99B(9):1237-43. https://doi.org/10.1302/0301-620X.99B9.BJJ-2017-0219. R1.

17. Yasin NF, Ajit Singh V, Saad M, Omar E. Which is the best method of sterilization for recycled bone autograft in limb salvage surgery: a radiological, biomechanical and histopathological study in rabbit. BMC Cancer. 2015;15:289. https://doi.org/10.1186/s12885-015-1234-9.

18. Klifto CS, Gandi SD, Sapienza A. Bone graft options in upper-extremity surgery. J Hand Surg Am. 2018;43(8):755-761.e752. https://doi.org/10. 1016/j.jhsa.2018.03.055.

19. Qu H, Guo W, Yang R, Li D, Tang S, Yang Y, Dong S, Zang J. Reconstruction of segmental bone defect of long bones after tumor resection by devitalized tumor-bearing bone. World J Surg Oncol. 2015;13:282. https://doi.org/10.1186/s12957-015-0694-3.

20. Delloye C, Banse X, Brichard B, Docquier PL, Cornu O. Pelvic reconstruction with a structural pelvic allograft after resection of a malignant bone tumor. J Bone Joint Surg Am. 2007;89(3):579-87. https://doi.org/ 10.2106/JBJS.E.00943.

21. Panagopoulos GN, Mavrogenis AF, Mauffrey C, Lesensky J, Angelini A, Megaloikonomos PD, Igoumenou VG, Papanastassiou J, Savvidou O, Ruggieri P, Papagelopoulos PJ. Intercalary reconstructions after bone tumor resections: a review of treatments. Eur J Orthop Surg Traumatol. 2017;27(6):737-46. https://doi.org/10.1007/s00590-017-1985-x.

22. Mankin HJ, Hornicek FJ, Raskin KA. Infection in massive bone allografts. Clin Orthop Relat Res. 2005;432:210-6. https://doi.org/10.1097/01.blo. 0000150371.77314 .52

23. Hinsenkamp M, Muylle L, Eastlund T, Fehily D, Noel L, Strong DM. Adverse reactions and events related to musculoskeletal allografts: reviewed by the World Health Organisation Project NOTIFY. Int Orthop. 2012;36(3):633-41. https://doi.org/10.1007/s00264-011-1391-7.

24. Zheng K, Yu XC, Hu YC, Shao ZW, Xu M, Wang BC, Wang F. Outcome of segmental prosthesis reconstruction for diaphyseal bone tumors: a multi-center retrospective study. BMC Cancer. 2019;19(1):638. https:// doi.org/10.1186/s12885-019-5865-0.

25. Azi ML, Teixeira AAA, Cotias RB, Joeris A, Kfuri M. Induced-membrane technique in the management of posttraumatic bone defects. JBJS Essent Surg Tech. 2019;9(2):e22. https://doi.org/10.2106/JBJS.ST.18. 00099.

26. Villemagne T, Bonnard C, Accadbled F, L'Kaissi M, de Billy B, Sales de Gauzy J. Intercalary segmental reconstruction of long bones after malignant bone tumor resection using primary methyl methacrylate cement spacer interposition and secondary bone grafting: the induced membrane technique. J Pediatr Orthop. 2011:31(5):570-6. https://doi. org/10.1097/BPO.0b013e31821ffa82.

27. Masquelet AC. Induced membrane technique: pearls and pitfalls. J Orthop Trauma. 2017;31(Suppl 5):S36-8. https://doi.org/10.1097/BOT. 0000000000000979

28. Fung B, Hoit G, Schemitsch E, Godbout C, Nauth A. The induced membrane technique for the management of long bone defects. Bone Joint J. 2020;102-B(12):1723-34. https://doi.org/10.1302/0301-620X.102B12. BJJ-2020-1125.R1.

29. Graci C, Maccauro G, Muratori F, Spinelli MS, Rosa MA, Fabbriciani C Infection following bone tumor resection and reconstruction with tumoral prostheses: a literature review. Int J Immunopathol Pharmacol. 2010;23(4):1005-13. https://doi.org/10.1177/039463201002300405.

30. Vidal L, Kampleitner C, Brennan MA, Hoornaert A, Layrolle P. Reconstruction of large skeletal defects: current clinical therapeutic strategies and future directions using 3D printing. Front Bioeng Biotechnol. 2020:8:61 . https://doi.org/10.3389/fbioe.2020.00061.

31. Bakri K, Stans AA, Mardini S, Moran SL. Combined massive allograft and intramedullary vascularized fibula transfer: the Capanna technique for lower-limb reconstruction. Semin Plast Surg. 2008;22(3):234-41. https:// doi.org/10.1055/s-2008-1081406.

32. Krieg AH, Lenze U, Schultze L, Gross MW, Haug M. Extracorporeal irradiation and reimplantation of tumor-bearing bone segments following diaphyseal sarcoma resection at the tibia. Anticancer Res. 2019;39(4):2015-23. https://doi.org/10.21873/anticanres.13312.

33. Beris AE, Lykissas MG, Korompilias AV, Vekris MD, Mitsionis GI, Malizos KN, Soucacos PN. Vascularized fibula transfer for lower limb reconstruction. Microsurgery. 2011;31(3):205-11. https://doi.org/10.1002/micr. 20841.

34. Kalra GS, Goel P, Singh PK. Reconstruction of post-traumatic long bone defect with vascularised free fibula: a series of 28 cases. Indian J Plast Surg. 2013;46(3):543-8. https://doi.org/10.4103/0970-0358.122013. 
35. Bumbasirevic M, Stevanovic M, Bumbasirevic V, Lesic A, Atkinson $H D$. Free vascularised fibular grafts in orthopaedics. Int Orthop. 2014;38(6):1277-82. https://doi.org/10.1007/s00264-014-2281-6.

36. Muramatsu K, Ihara K, Shigetomi M, Kawai S. Femoral reconstruction by single, folded or double free vascularised fibular grafts. Br J Plast Surg. 2004;57(6):550-5. https://doi.org/10.1016/j.bjps.2003.08.021.

37. Mukherjee AN, Pal AK, Singharoy D, Baksi D, Nath C. Harvesting the free fibular graft: a modified approach. Indian J Orthop. 2011;45(1):53-6. https://doi.org/10.4103/0019-5413.73657.

38. Bi ZG, Han XG, Fu CJ, Cao Y, Yang CL. Reconstruction of large limb bone defects with a double-barrel free vascularized fibular graft. Chin Med J. 2008;121(23):2424-8.

39. Kovoor CC, Jayakumar R, George V, Padmanabhan V, Guild A, Viswanath S. Vascularized fibular graft in infected tibial bone loss. Indian J Orthop. 2011;45(4):330-5. https://doi.org/10.4103/0019-5413.82337.

40. Roddy E, DeBaun MR, Daoud-Gray A, Yang YP, Gardner MJ. Treatment of critical-sized bone defects: clinical and tissue engineering perspectives. Eur J Orthop Surg Traumatol. 2018;28(3):351-62. https://doi.org/10. 1007/s00590-017-2063-0.

41. Wieser K, Modaressi K, Seeli F, Fuchs B. Autologous double-barrel vascularized fibula bone graft for arthrodesis of the shoulder after tumor resection. Arch Orthop Trauma Surg. 2013;133(9):1219-24. https://doi. org/10.1007/s00402-013-1795-5.

42. Chu CH, Jou IM, Shieh SJ. Reconstruction of a massive femoral bone defect using a double-barreled free vascularized fibular bone graft after wide resection of femoral chondrosarcoma. Kaohsiung J Med Sci. 2009;25(10):552-8. https://doi.org/10.1016/S1607-551X(09)70548-0.

43. Estrella EP, Wang EH. A comparison of vascularized free fibular flaps and nonvascularized fibular grafts for reconstruction of long bone defects after tumor resection. J Reconstr Microsurg. 2017;33(3):194-205. https://doi.org/10.1055/s-0036-1594299.

44. McCullough MC, Arkader A, Ariani R, Lightdale-Miric N, Tolo V, Stevanovic M. Surgical outcomes, complications, and long-term functionality for free vascularized fibula grafts in the pediatric population: a 17-year experience and systematic review of the literature. J Reconstr Microsurg. 2020;36(5):386-96. https://doi.org/10.1055/s-0040-1702147.

45. Houdek MT, Bayne CO, Bishop AT, Shin AY. The outcome and complications of vascularised fibular grafts. Bone Joint J. 2017;99-B(1):134-8. https://doi.org/10.1302/0301-620X.99B1.BJJ-2016-0160.R1.

46. Liu S, Tao S, Tan J, Hu X, Liu H, Li Z. Long-term follow-up of fibular graft for the reconstruction of bone defects. Medicine. 2018;97(40): e12605. https://doi.org/10.1097/MD.0000000000012605.

47. Capanna R, Bufalini C, Campanacci M. A new technique for reconstructions of large metadiaphyseal bone defects. Orthop Traumatol. 1993;2(3):159-77. https://doi.org/10.1007/BF02620523.

48. Rabitsch K, Maurer-Ertl W, Pirker-Fruhauf U, Wibmer C, Leithner A. Intercalary reconstructions with vascularised fibula and allograft after tumour resection in the lower limb. Sarcoma. 2013;2013: 160295. https://doi.org/10.1155/2013/160295.

49. Pederson WC, Person DW. Long bone reconstruction with vascularized bone grafts. Orthop Clin North Am. 2007;38(1):23-35. https://doi.org/ 10.1016/j.ocl.2006.10.006.

50. Van Den Heuvel SCM, Winters HAH, Ultee KH, Zijlstra-Koenrades N, Sakkers RJB. Combined massive allograft and intramedullary vascularized fibula transfer: the Capanna technique for treatment of congenital pseudarthrosis of the tibia. Acta Orthop. 2020;91(5):605-10. https://doi. org/10.1080/17453674.2020.1773670.

51. Lee JH, Han CS, Baek JH. Onlay vascularized fibular grafting as a salvage procedure for the management of nonunion after reconstruction of the femur following tumor resection. J Orthop Surg. 2018;26(3):2309499018802490. https://doi.org/10.1177/2309499018 802490.

52. Ceruso M, Falcone C, Innocenti M, Delcroix L, Capanna R, Manfrini M. Skeletal reconstruction with a free vascularized fibula graft associated to bone allograft after resection of malignant bone tumor of limbs. Handchir Mikrochir Plast Chir. 2001;33(4):277-82. https://doi.org/10. 1055/s-2001-16597.

53. Campanacci DA, Totti F, Puccini S, Beltrami G, Scoccianti G, Delcroix $L$, Innocenti M, Capanna R. Intercalary reconstruction of femur after tumour resection: is a vascularized fibular autograft plus allograft a long-lasting solution? Bone Joint J. 2018;100-B(3):378-86. https://doi. org/10.1302/0301-620X.100B3.BJJ-2017-0283.R2.

54. Errani C, Ceruso M, Donati DM, Manfrini M. Microsurgical reconstruction with vascularized fibula and massive bone allograft for bone tumors. Eur J Orthop Surg Traumatol. 2019;29(2):307-11. https://doi. org/10.1007/s00590-018-2360-2.

55. Ebraheim NA, Elgafy $H, X u$ R. Bone-graft harvesting from iliac and fibular donor sites: techniques and complications. J Am Acad Orthop Surg. 2001;9(3):210-8. https://doi.org/10.5435/00124635-20010 5000-00007.

56. Tonoli C, Bechara AH, Rossanez R, Belangero WD, Livani B. Use of the vascularized iliac-crest flap in musculoskeletal lesions. Biomed Res Int. 2013;2013: 237146. https://doi.org/10.1155/2013/237146.

57. Roberts TT, Rosenbaum AJ. Bone grafts, bone substitutes and orthobiologics: the bridge between basic science and clinical advancements in fracture healing. Organogenesis. 2012;8(4):114-24. https:// doi.org/10.4161/org.23306.

58. Lei P, Du W, Liu H, Wu P, Zhou Z, Yu F, Qing L, Pan D, Liu R, Zeng L, Cao Z, Ou Q, Tang J. Free vascularized iliac bone flap based on deep circumflex iliac vessels graft for the treatment of osteonecrosis of femoral head. J Orthop Surg Res. 2019;14(1):397. https://doi.org/10. 1186/s13018-019-1440-2.

59. Takemoto RC, Fajardo M, Kirsch T, Egol KA. Quantitative assessment of the bone morphogenetic protein expression from alternate bone graft harvesting sites. J Orthop Trauma. 2010;24(9):564-6. https://doi. org/10.1097/BOT.0b013e3181ed29a6.

60. Dawson J, Kiner D, Gardner W 2nd, Swafford R, Nowotarski PJ. The reamer-irrigator-aspirator as a device for harvesting bone graft compared with iliac crest bone graft: union rates and complications. J Orthop Trauma. 2014;28(10):584-90. https://doi.org/10.1097/BOT. 0000000000000086.

61. Kessler P, Thorwarth M, Bloch-Birkholz A, Nkenke E, Neukam FW. Harvesting of bone from the iliac crest-comparison of the anterior and posterior sites. Br J Oral Maxillofac Surg. 2005;43(1):51-6. https:// doi.org/10.1016/j.bjoms.2004.08.026.

62. Zhu JF, Xu WX, Hu Q, Wu TQ, Liu H. Iliac bone harvesting techniques for bone reconstruction. Comparative study between tricortical bone harvesting vs trapdoor technique. Ther Clin Risk Manag. 2020;16:55965. https://doi.org/10.2147/TCRM.S257336.

63. Myeroff C, Archdeacon M. Autogenous bone graft: donor sites and techniques. J Bone Joint Surg Am. 2011;93(23):2227-36. https://doi. org/10.2106/JBJS.J.01513.

64. Hu R, Hearn T, Yang J. Bone graft harvest site as a determinant of iliac crest strength. Clin Orthop Relat Res. 1995;310:252-6.

65. Varga E, Hu R, Hearn TC, Woodside T, Yang JP. Biomechanical analysis of hemipelvic deformation after corticospongious bone graft harvest from the posterior iliac crest. Spine. 1996;21(13):1494-9. https://doi. org/10.1097/00007632-199607010-00002.

66. Calori GM, Colombo M, Mazza EL, Mazzola S, Malagoli E, Mineo GV. Incidence of donor site morbidity following harvesting from iliac crest or RIA graft. Injury. 2014;45(Suppl 6):S116-120. https://doi.org/ 10.1016/j.injury.2014.10.034.

67. Dehghan N, Schemitsch EH. Extended applications of the reamer-irrigator-aspirator (RIA) system. Injury. 2017;48(Suppl 1):S47-51. https:// doi.org/10.1016/j.injury.2017.04.025.

68. Madison RD, Nowotarski PJ. The reamer-irrigator-aspirator in nonunion surgery. Orthop Clin North Am. 2019;50(3):297-304. https://doi. org/10.1016/j.ocl.2019.03.001.

69. Spiegelberg B, Parratt T, Dheerendra SK, Khan WS, Jennings R, Marsh DR. Ilizarov principles of deformity correction. Ann R Coll Surg Engl. 2010;92(2):101-5. https://doi.org/10.1308/003588410X1251883643 9326.

70. Lesensky J, Prince DE. Distraction osteogenesis reconstruction of large segmental bone defects after primary tumor resection: pitfalls and benefits. Eur J Orthop Surg Traumatol. 2017;27(6):715-27. https://doi.org/10.1007/s00590-017-1998-5.

71. Alzahrani MM, Anam E, AlQahtani SM, Makhdom AM, Hamdy RC. Strategies of enhancing bone regenerate formation in distraction osteogenesis. Connect Tissue Res. 2018;59(1):1-11. https://doi.org/ 10.1080/03008207.2017.1288725. 
72. Matsubara $\mathrm{H}$, Tsuchiya $\mathrm{H}$. Treatment of bone tumor using external fixator. J Orthop Sci. 2019;24(1):1-8. https://doi.org/10.1016/j.jos. 2018.06.022.

73. Rath B, Hardes J, Tingart M, Braunschweig T, Eschweiler J, Migliorini F. Resection margins in soft tissue sarcomas. Orthopade. 2019;48(9):768-75. https://doi.org/10.1007/s00132-019-03795-6.

74. Tsuchiya H, Abdel-Wanis ME, Sakurakichi K, Yamashiro T, Tomita K. Osteosarcoma around the knee. Intraepiphyseal excision and biological reconstruction with distraction osteogenesis. J Bone Joint Surg Br. 2002;84(8):1 162-6. https://doi.org/10.1302/0301-620x.84b8.13330.

75. Demiralp B, Ege T, Kose O, Yurttas Y, Basbozkurt M. Reconstruction of intercalary bone defects following bone tumor resection with segmental bone transport using an llizarov circular external fixator. J Orthop Sci. 2014;19(6):1004-11. https://doi.org/10.1007/ s00776-014-0632-1.

76. Schep NW, van Lieshout EM, Patka P, Vogels LM. Long-term functional and quality of live assessment following post-traumatic distraction osteogenesis of the lower limb. Strateg Trauma Limb Reconstr. 2009;4(3):107-12. https://doi.org/10.1007/s11751-009-0070-3.

77. Karger C, Kishi T, Schneider L, Fitoussi F, Masquelet AC, French Society of Orthopaedic Surgery and Traumatology. Treatment of posttraumatic bone defects by the induced membrane technique. Orthop Traumatol Surg Res. 2012;98(1):97-102. https://doi.org/10.1016/j.otsr. 2011.11.001.

78. Gouron R. Surgical technique and indications of the induced membrane procedure in children. Orthop Traumatol Surg Res. 2016;102(1 Suppl):S133-139. https://doi.org/10.1016/j.otsr.2015.06.027.

79. Mathieu L, Tossou-Odjo L, de l'Escalopier N, Demoures T, Baus A, Brachet $\mathrm{M}$, Masquelet AC. Induced membrane technique with sequential internal fixation: use of a reinforced spacer for reconstruction of infected bone defects. Int Orthop. 2020:44(9):1647-53. https://doi. org/10.1007/s00264-020-04735-2.

80. Pereira R, Perry WC, Crisologo PA, Liette MD, Hall B, Hafez Hassn SG, Masadeh S. Membrane-induced technique for the management of combined soft tissue and osseous defects. Clin Podiatr Med Surg. 2021;38(1):99-110. https://doi.org/10.1016/j.cpm.2020.09.005.

81. Taylor BC, French BG, Fowler TT, Russell J, Poka A. Induced membrane technique for reconstruction to manage bone loss. J Am Acad Orthop Surg. 2012;20(3):142-50. https://doi.org/10.5435/ JAAOS-20-03-142.

82. Lu Y, Wang J, Yang Y, Yin Q. Bone defects are repaired by enhanced osteogenic activity of the induced membrane: a case report and literature review. BMC Musculoskelet Disord. 2021;22(1):447. https:// doi.org/10.1186/s12891-021-04317-2.

83. Mauffrey C, Hake ME, Chadayammuri V, Masquelet AC. Reconstruction of long bone infections using the induced membrane technique: tips and tricks. J Orthop Trauma. 2016;30(6):e188-193. https:// doi.org/10.1097/BOT.00000000000000500.

84. Gouron R, Petit L, Boudot C, Six I, Brazier M, Kamel S, Mentaverri R. Osteoclasts and their precursors are present in the induced-membrane during bone reconstruction using the Masquelet technique. J Tissue Eng Regen Med. 2017;11(2):382-9. https://doi.org/10.1002/ term.1921.

85. Wu PK, Chen CF, Chen CM, Cheng YC, Tsai SW, Chen TH, Chen WM. Intraoperative extracorporeal irradiation and frozen treatment on tumor-bearing autografts show equivalent outcomes for biologic reconstruction. Clin Orthop Relat Res. 2018;476(4):877-89. https:// doi.org/10.1007/s11999.00000000000000022.

86. Ogura K, Miyamoto S, Sakuraba M, Fujiwara T, Chuman H, Kawai A. Intercalary reconstruction after wide resection of malignant bone tumors of the lower extremity using a composite graft with a devitalized autograft and a vascularized fibula. Sarcoma. 2015;2015: 861575. https://doi.org/10.1155/2015/861575.

87. Spira E, Lubin E. Extracorporeal irradiation of bone tumors. A preliminary report. Isr J Med Sci. 1968;4(5):1015-9.

88. Pruksakorn D, Kongthavonskul J, Teeyakasem P, Phanphaisarn A, Chaiyawat P, Klangjorhor J, Arpornchayanon O. Surgical outcomes of extracorporeal irradiation and re-implantation in extremities for high grade osteosarcoma: a retrospective cohort study and a systematic review of the literature. J Bone Oncol. 2019;14: 100210. https://doi. org/10.1016/j.jbo.2018.100210.
89. Oike N, Kawashima H, Ogose A, Hatano H, Ariizumi T, Kaidu M, Aoyama H, Endo N. Long-term outcomes of an extracorporeal irradiated autograft for limb salvage operations in musculoskeletal tumours: over ten years' observation. Bone Joint J. 2019;101-B(9):1151-9. https://doi.org/10.1302/0301-620X.101B9.BJJ-2019-0090.R1.

90. Mihara A, Muramatsu K, Hashimoto T, Iwanaga R, Ihara K, Sakai T. Combination of extracorporeally-irradiated autograft and vascularized bone graft for reconstruction of malignant musculoskeletal tumor. Anticancer Res. 2020;40(3):1637-43. https://doi.org/10.21873/ anticanres.14113.

91. Takenaka S, Araki N, Ueda T, Kakunaga S, Imura Y, Hamada KI, Outani H, Naka N, Myoui A, Yoshikawa H. Clinical outcomes of osteoarticular extracorporeal irradiated autograft for malignant bone tumor. Sarcoma. 2020;2020:9672093. https://doi.org/10.1155/2020/9672093.

92. Liu T, Guo X, Zhang X, Li Z, Zhang Q. Reconstruction with pasteurized autograft for primary malignant bone tumor of distal tibia. Bull Cancer. 2012;99(9):87-91. https://doi.org/10.1684/bdc.2012.1626.

93. Lee SY, Jeon DG, Cho WH, Song WS, Kim BS. Are pasteurized autografts durable for reconstructions after bone tumor resections? Clin Orthop Relat Res. 2018:476(9):1728-37. https://doi.org/10.1007/ s11999.00000000000000100.

94. Takata M, Sugimoto N, Yamamoto N, Shirai T, Hayashi K, Nishida H, Tanzawa Y, Kimura H, Miwa S, Takeuchi A, Tsuchiya H. Activity of bone morphogenetic protein-7 after treatment at various temperatures: freezing vs. pasteurization vs. allograft. Cryobiology. 2011;63(3):2359. https://doi.org/10.1016/j.cryobiol.2011.09.001.

95. Guo X, Li X, Liu T, Shuai C, Zhang Q. Pasteurized autograft reconstruction after resection of periacetabular malignant bone tumours. World J Surg Oncol. 2017;15(1):13. https://doi.org/10.1186/ s12957-016-1065-4.

96. Igarashi K, Yamamoto N, Shirai T, Hayashi K, Nishida H, Kimura H, Takeuchi A, Tsuchiya $\mathrm{H}$. The long-term outcome following the use of frozen autograft treated with liquid nitrogen in the management of bone and soft-tissue sarcomas. Bone Joint J. 2014;96-B(4):555-61. https://doi.org/10.1302/0301-620X.96B4.32629.

97. Kimura H, Yamamoto N, Shirai T, Nishida H, Hayashi K, Tanzawa Y, Takeuchi A, Miwa S, Tsuchiya H. Clinical outcome of reconstruction using frozen autograft for a humeral bone tumor. Anticancer Res. 2016;36(12):6631-5. https://doi.org/10.21873/anticanres.11270.

98. Garg SK, Aggarwal P, Virk J, Punia RPS, Dimri K, Jindal R. Limb salvage using liquid nitrogen-treated tumour-bearing autograft: a single institutional experience of 10 patients. Indian J Orthop. 2020;54(2):200-7. https://doi.org/10.1007/s43465-019-00001-9.

99. Zekry KM, Yamamoto N, Hayashi K, Takeuchi A, Higuchi T, Abe K, Taniguchi Y, Alkhooly A, Abd-Elfattah AS, Fouly EH, Ahmed AR, Tsuchiya H. Intercalary frozen autograft for reconstruction of malignant bone and soft tissue tumours. Int Orthop. 2017;41(7):1481-7. https://doi.org/10. 1007/s00264-017-3446-x.

100. Tsuchiya H, Wan SL, Sakayama K, Yamamoto N, Nishida H, Tomita K. Reconstruction using an autograft containing tumour treated by liquid nitrogen. J Bone Joint Surg Br. 2005;87(2):218-25. https://doi. org/10.1302/0301-620x.87b2.15325.

101. Hamed Kassem Abdelaal A, Yamamoto N, Hayashi K, Takeuchi A, Miwa S, Tsuchiya H. Epiphyseal sparing and reconstruction by frozen bone autograft after malignant bone tumor resection in children. Sarcoma. 2015;2015: 892141. https://doi.org/10.1155/2015/892141.

102. Shimozaki S, Yamamoto N, Shirai T, Nishida H, Hayashi K, Tanzawa Y, Kimura H, Takeuchi A, Igarashi K, Inatani H, Kato T, Tsuchiya H. Pedicle versus free frozen autograft for reconstruction in malignant bone and soft tissue tumors of the lower extremities. J Orthop Sci. 2014;19(1):156-63. https://doi.org/10.1007/s00776-013-0487-x.

103. Lu Y, Zhu H, Huang M, Zhang C, Chen G, Ji C, Wang Z, Li J. Is frozen tumour-bearing autograft with concurrent vascularized fibula an alternative to the Capanna technique for the intercalary reconstruction after resection of osteosarcoma in the lower limb? Bone Joint J. 2020;102-B(5):646-52. https://doi.org/10.1302/0301-620X.102B5.BJJ2019-1380.R1.

104. Palumbo BT, Henderson ER, Groundland JS, Cheong D, Pala E, Letson $G D$, Ruggieri P. Advances in segmental endoprosthetic reconstruction for extremity tumors: a review of contemporary designs and 
techniques. Cancer Control. 2011;18(3):160-70. https://doi.org/10. 1177/107327481101800303.

105. Henderson ER, Groundland JS, Pala E, Dennis JA, Wooten R, Cheong D, Windhager R, Kotz RI, Mercuri M, Funovics PT, Hornicek FJ, Temple $H T$, Ruggieri P, Letson GD. Failure mode classification for tumor endoprostheses: retrospective review of five institutions and a literature review. J Bone Joint Surg Am. 2011;93(5):418-29. https://doi.org/10 2106/JBJS.J.00834.

\section{Publisher's Note}

Springer Nature remains neutral with regard to jurisdictional claims in published maps and institutional affiliations.
Ready to submit your research? Choose BMC and benefit from:

- fast, convenient online submission

- thorough peer review by experienced researchers in your field

- rapid publication on acceptance

- support for research data, including large and complex data types

- gold Open Access which fosters wider collaboration and increased citations

- maximum visibility for your research: over 100M website views per year

At BMC, research is always in progress.

Learn more biomedcentral.com/submissions 